\title{
Crime and Punishment, Sin and Retribution: From the History of Religious and Legal Traditions of East and West
}

Jana V. Beznosova

Anna N. Kondratyeva

Vera. B. Romanovskaya

N. I. Lobachevsky State University of Nizhny Novgorod

Eduard. B. Kurzenin

Institute of Business Studies of the Russian Presidential Academy of National Economy and Public Administration

E-mail: sci.publ@gmail.com

\section{Doi:10.5901/mjss.2015.v6n6s2p662}

\section{Abstract}

The concepts of "sin" and "crime", "reward" and "punishment" are found in the ancient Indian religious and ethical treatises dharmasastra Manu, Yajnavalkya and Vishnu, and canon law manuscripts of Western Europe of early and High Middle Ages. The issue of the relationship between Eastern and Western religious and legal views is examined in the paper. The authors defend the idea that religion is a key component having influenced the basic principles of morality and law, the construction of crime and punishment concepts. It is proved that officially already in the early Middle Ages, both in the East and in the West the sources of law differentiate between the sinful and criminal acts, which, however, at that time still was not clear and unambiguous. Based on the application of comparative analysis, hermeneutics, contextual analysis, historical, legal and other methods while studying the dharmasastra texts, the authors propose several classifications of sins against various reasons: according to the form of guilt, the degree of public danger, according to the order imposition and execution of the expiation. In turn, the methods mentioned above contributed to the detailed study of the medieval sources of canon law, which allowed us to formulate the thesis on the official differentiation between the concepts of "sin" and "crime" only after the adoption of the Decretum Gratiani to have been the main source of Western canon law in the Middle Ages.

Keywords: retribution, sin, canon law, punishment, crime, religion.

\section{Introduction}

Religion has always been the basis of public life everywhere and in various epochs. The origins of the currently existing legal institutions of both Western and Oriental legal systems go back to the religious rites and doctrines of the late antiquity, the early and High Middle Ages. From the ancient times, the mankind have been trying to understand and comprehend such phenomena as death, sin, forgiveness, salvation, punishment, retribution, etc. In the Middle Ages the best minds of their time formulated "new ideas on the relation of the divine to the human and faith to the human brain" (Harold J. Berman,1983). In this article the authors, discussing the Oriental and Western concepts of sin, crime, redemption and punishment turn to the ancient Indian tradition of the Oriental and Western ideas of canon law. The importance of turning to those systems is that they preserved their influence on the legal conscience of the people of the western and oriental cultures, and strike a chord in the contemporaries' minds and hearts. So, the ancient Indian law modified in the Middle Ages formed the basis of the existing Hindu Law (Jayaswa K. P., 1930) and currently existing legal systems of the Western countries are secular sediment of the religious beliefs and ideas which historically were expressed in religious ceremonies and doctrines and later in terms and values of the law. In that regard, V.V. Yesipov justly said "Jesus Christ's teachings had shed new light on the attitude to the criminal person. Having a profound impact on all aspects of private, social and political life, Christianity had had a similar impact on the basic principles of morality and law and on the formulating of the crime and punishment concepts" (Yesipov V. V., 1894).

In the course of the religious and legal views evolution in the western and eastern world, the concept of a sin, crime, punishment and retribution was gradually changing and differentiating.

Based on the text dharmashastra we can conclude that in the Oriental tradition: firstly, sins incurred ritual 
abomination upon the wrongdoer. Until such a person executed redemption, he was ritually considered to be "evil" for other people. Crimes did not bring any ritual impurity, the offender was considered to be guilty, but not "impure" (except those criminal offences, which simultaneously were thought to be sinful, for example, four "great sins"). Secondly, the man was retributed for the sins after death and further rebirth in the non-human appearance or with physical deficiencies, but he could not avoid that, having redeemed the sin. The offender was subject to the secular punishment. Thirdly, the redemption was prescribed by the learned Brahmin or Parishad (Dharmashastra Yajnavalkya, III. 300) and the punishment was imposed by the tsar's court (Dharmashastr Yajnavalkya, I. 368).

In Western Canon law the concepts of a sin and a crime in the High Middle Ages are delineated (although they are in the state permanent interaction) and gain independent meaning. Sins are delimitated according to the church and the secular court jurisdiction, however, the concept of a "secular crime" eventually, was not developed. Despite this, the conditions under which the secular crimes committed by the clergy were transferred to the category of sins were clearly defined.

Gradually the category of retribution disappears from the religious texts and the structure of atonement for sin is introduced. There appears a completely new concept: the baptized Christians died in repentance, could be assured of that their natural inclination to sin is already forgiven and that their actual sins could be fully redeemed through the relevant punishment in this life until the last day came.

\section{Methods}

Due to the specific nature of the subject of the research, the main method used by the authors is a dialectic one as it implies the use of the systematic approach to the phenomena under study, their examining in the development taking into account the definite historical realities. A system approach in the framework of the theme investigated is of particular importance as the most important institutions of the Western and Oriental religious and legal traditions are the subject of this study. Along with the above said methods a socio-cultural approach is used which involves the social, religious, cultural and dogmatic layers of society activities in the era of ancient and medieval times.

While studying dharmashastra texts, the methods of comparative analysis, hermeneutics, contextual analysis, historical, legal and comparative historical analysis were applied. The general philosophical methods of analysis and synthesis, induction and deduction were the basic ones.

\section{The Main Part}

Antiquity and the Middle Ages are objectively acknowledged today as those important periods in the development of the political structure of the European society, when the legal concepts still used in the political and legal sphere were formulated. Those concepts supported to enunciate the idea of the universal law and order. In this regard, the sources of canon law to have been understudied in the Russian jurisprudence are of particular interest. However, the foreign experts acknowledge their importance in the course of the secular medieval law establishing (Landau, 2013 Winroth, 2004). The analysis of the early sources of canon law of the Roman Catholic Church suggests the indivisibility of such phenomena as "sin" and "crime' in the early Middle Ages.

The thesis said above is confirmed by many sources of that time, in particular, in the Decrees of Pope Leo (V c.) to have been a part of "Dionisiana" (Collectio Dionysiana, 1975) where Pope Leo while dwelling on merchants' incomes said that "it is hard to avoid a sin among buying and selling transactions'. This document also contains the concept of "retribution".

In the later source of canon law - "The Ancient Gallic Collection" (VI-VII centuries) (Collectio Vêtus Gallica, 1975) it is said that a criminal (a sinner), while committing a crime (a sin) turns out to be facing not only the humane judgement but the godly judgement as well. Accordingly, the concepts being examined in this article remain still interchangeable. It should be noted that in the early Middle Ages the clergy played a crucial role in the "secular" legal proceedings. The system of sacramental penance (punishment) was mainly applied with the purpose of taking care of the human souls, the resumption of the moral life and restoration of the truthful relationships with God. The secular court sanctions in the early Middle Ages were not aimed at punishment but honor recovery, reconciliation and restoration of peace. Such an attitude to the institution of punishment demonstrates the significant influence of religion and morality upon the legal relationships. For example, trade in religious institutions, positions, goods and sacraments - simony - was condemned in the medieval Western society (Brandt, 2007). Pope Gregor I the Great, who considered all the manifestations of simony to be heresy and identified three types of it. He saw a sin not only in the situation when sale and purchase of the ecclesiastical order were effected for money, but when in return to the post some favours and services were provided, as well as so-called 
munus and lingua (flattery and petition) (Kempf, 1966). Moreover, he believed that in all three cases, anyone who was involved in the sinful activities was to be considered to be a heretic. From the legal point of view it is important that simony after Gregor the Great's reforms was regarded not only as a sin but also as a dogmatic denial of the divine nature, which during the High Middle Ages was transforming into key offenses against the church.

In the era of the High Middle Ages, after the disintegration of the Christian Church into the Orthodox (Eastern) and the Catholic (Western) Church, for the first there takes place a doctrinal distinction between a sin and a crime. Ivo of Chartres Decree was the first source of canon law of the Roman Catholic Church in the late $11^{\text {th }}$ century when though not very clearly but still the distinction was made between crimes and sins (Divus Ivo Carnotensis. Décretum, 1975) This document said that all the existing regulations and prohibitions could be both flexible (mobiles) and inflexible (immobiles) (Sprandel, 1962). Those provisions which were established by the eternal (God's) law were considered to be inflexible. God's laws compliance brings salvation, and failure to observe them brings alienation. "Those things which were created with the descendants diligence (by secular population) for usefulness reasons, however, not being the mainstream condition for salvation but for more reliable preservation were considered to be a flexible regulation. Ivo of Chartres in his "Decree" does not say anything about the reward, which was mentioned in earlier sources, however, he speaks in detail about redemption. For example, he pointed out that the prohibitions to be directed against the vices (do not kill, do not commit adultery, etc.) are also referred to the inflexible ones. Anyone who dares to neglect them will not be worth of the Kingdom of God. Ivo explained it by the fact that compliance with the requirements and prohibitions gave salvation, but neglecting them resulted in the complete destruction and those who did not observe the regulations could not be issued any dispensation (Beznosova, Ya. V., Kondratyeva, A. N., Romanovskaya, V. B., Fedyushkina, A. I., 2015). Those regulations, which were legalized by the descendants' diligence for strong discipline reasons or salvation preservation, could only be overcome with thoroughly weighed dispensation if there follows worthy or useful compensation. Thus, for the first time in canon law of the Catholic Church the "structure of redemption" for violation of the prohibitions and regulations was established.

By the end of the first half of the $12^{\text {th }}$ century, theologians and lawyers of Western Europe had already had a clear distinction between the sins and the crimes. A distinction was made between the criminal sins and all other sins. The former differed from all other sins by the fact that their sinfulness, that is their directionality against God, was measured by the criteria of the church law applied by the ecclesiastical judges acting by right of their jurisdiction not by the criteria of the "divine right" applied by God himself through the priests acting by right of their order (Berman,1983).

The theoretical underpinning of the category of "crime" was done by Pierre Abelard in his work "Ethics" (Gratianus. Concordia discordantium canonum, 1975), where he put forward three main conditions necessary for the jurisdiction of sin to the ecclesiastical court: 1 . it must be a grievous sin. The severity of the sin was determined on the basis of the traditional division into mortal sins and minor ones (venial, mild). The $12^{\text {th }}$ century canonists said that only the mortal sin made a crime and at the same time not every mortal sin, but only the one which by the circumstances of its committing was heavy enough to deserve criminal punishment under orders of the ecclesiastical court; 2 . A sin was to be manifested in some external action. It was this thesis that was laid in the foundation of the secular legal systems in the West; 3 . The action was to be irritating the church. This position was also supported by the canonists.

Pierre Abelard's doctrine had had a major impact on the formation of the criminal science of canon law in particular and on the development of the entire Christian law in general. "Concordantia Discordantium Canonum" or "Gratian's Decree" as it is more often called in modern legal literature, adopted a number of ideas of the prominent theologians and combined the lawyers' point of view, who at that time were actively starting to use the colossal body of the Roman law. "Gratian's Decree" is not by chance, considered to have drawn the invisible boundary between jus antiquum and jus novum.

John Gratian states that "everything being fas is taken under the name of the divine or natural law and under the name of the humane law they consider the customs, properly recorded, stored and transmitted" (Stiegler, 1897). It is this thesis that has become the key one to understand some major institutions, in particular, studied in this article. Since the time of "the Decree" coming out, not only doctrinal, but a formal distinction between a sin and a crime had been stated. The definition of dispensation ("temporary mitigation of the strictness of the law out of the necessity or for the good of the Church), which we see in John Gratian, is identical to the definition given by Ivo of Chartres. The only difference is that Gratian distinguishes two kinds of dispensation: post factum and ante factum, however, he does not provide any further comments on this issue (Menski, 2001).

The distinction between the sin and the crime with adoption of "Gratian's Decree" however, had not resolved the main problem: who was to define "secular crimes": the Church or the secular authorities? Finding an answer to this question adds another issue to the analysis of the crime and the sin relation. The Church did not give a definition to "secular crimes", however, it was the Catholic Church that determined the conditions under which the secular crimes 
committed by members of the clergy, became sins. The Ecclesiastical Court at the time effected proceedings in respect of not only the clergy, but also, in some cases, against the laity (heresy, danism, adultery, etc.). This draws to the conclusion that the Church possessed competence in the cases where the crimes had a special moral and ideological aspect and they were committed against the church property and the clergy. Thus, the element of sinfulness in the offense was a very important basis for the claims of the church for jurisdiction over the offence.

Addressing the Oriental law tradition shows that one of the most important categories of the traditional Indian culture is the concept of dharma as a certain moral and ethical setting required to each individual depending on his/her belonging to the particular social group (varna) and which one should hold on to during his/her entire lifetime. To help the individual to follow his/her dharma special treatises were drawn up - dharmashastra containing religious, ethical and legal regulations as a single entity (Samozvatsev, 2001).

The co-relation of "sin" and "crime" concepts can be clearly seen in the texts of the ancient Indian dharmashastra Manu and Yajnavalkya. As it was pointed out by a famous Russian historian A.M. Samozvatsev that "the concepts of "sin" and "crime" in the ancient Indian law, strictly speaking were not differentiated and India in this regard was not an exception. The range of semantic nuances here was largely determined by the social (cultural) environment, since the more the human's behavior was ritualized, the more the delict committed gained the note of sinfulness" (Olivelle, 2009).

In late Vedantic literature the difference between a criminal and a sinful act also remained elusive. However, in the later tradition these terminological differences become quite tangible that can be traced by the example of dharmashastra with their secular sections (radzhadharma) and religious (prayashchitta) law (Olivelle, 2009).

Compositionally, "the majority of the ancient Indian dharmashastra included three sections devoted, respectively, to the religious rituals (Adjara), judicial issues (vyavahara) and redemption (prayashchitta)" (Beznosova, Ya. V., Kondratyeva, A. N., Romanovskaya, V. B., Fedyushkina, A. I., 2015)

In vyavahara section, we find denotation onto different types of offenses, which the king was to fight with by imposing punishment on criminals. The section devoted to redemption contains a list of various categories of sins and a description of redemptive ceremonies due to which the material of prayashchitta (redemption) is given in the terms of ritual abomination and purification from the filth. However, it is not difficult to notice that a number of acts, recognized to be criminal from the viewpoint of the secular law at the same time have the status of sinful acts in prayashchitta dharmashastra where a expurgatory ceremony is recommended for those who have committed such acts.

In this regard, the issue of co-relation between "sin" and "crime" in the ancient Indian tradition of dharmashastra is of particular interest. Numerous materials to be analyzed are found in the redemption (prayashchitta) section of dharmashastra Manu and Yajnavalkya.

The narration of the prayashchitta in the said dharmashastra begins with the list of the penalty imposed on the person who has committed a sinful act. At the same time, the idea of a penalty in the Shastra is directly connected with the Hindu concepts of karma and samsara. In the simplified form, it is expressed in the fact that as a result of the sinful acts, a human being is born in the next life in the form of an animal or a plant or he/she carries some disfigurement in the his/her appearance or other physical deficiencies for the entire lifetime or in the subsequent birth: "Some villains are subjected to change in their appearance due to the crimes committed in this world or in a former life ... Thus, owing to the sin residue of the former wrongdoing, mentally defected, dumb, blind, deaf people and those with an ugly appearance despised by the pious people are born" (Dharmashastra Manu, XI. 48, 53) (Stenzler. 1849), "having turned into an animal as a result of the penalty for their behavior, sinners eventually born to be unhappy, poor and inferior men" (Dharmashastra Yajnavalkya, III. 217) (Lubin. 2007).

To avoid such consequences, sinners are given the opportunity to atone for the sin through appropriately executed repentance, because "having freed themselves from the sins, they are born in a high-standing family to be wealthy, knowledgeable in the sacred writings and provided with money and grain" (Dharmashastra Yajnavalkya, III. 218).

At the same time committing repentance or a refusal to commit one is a human being's voluntary choice, which can be affected only by his/her own internal mental excruciations: "If there is some heaviness in his heart after committing wrongdoing, then one must execute austerities until that heaviness disappears" (Dharmashastra Manu, XI. 234) (Stenzler. 1849). "As it is pointed out by the American scholar T. Lubin, in this case, not merely hearty pacification was emanating sought by the sinner, but also quasi-physical purification from the sin traces with his/her internal decision not to commit such an act again (Samozvatsev , 1994): "As his/her mind condemns the criminal act, so his/her body is released from the sin" (Dharmashastra Manu, XI. 230) (Stenzler. 1849), "Therefore, he/she is exempted from sin, having repented after it; he/she need not do it again: a man is purified by having stopped wrongdoing" (Dharmashastra Manu, XI. 231) (Stenzler, 1849).

Dharmashastra enlists the paths leading to Fall of man to be failure to comply with the established order, executing disapproved actions, immoderation (propensity to mundane pleasures) (Dharmashastra Manu, XI. 44; Dharmashastra 
Yajnavalkya, III. 219), and also it contains a reference to over eighty kinds of sinful acts that can be classified as such on various grounds.

For instance, according to the type of guilt they are singled out as follows: a) deliberate sins which were to not only be atoned but also were imposed with a secular punishment by the royal court (actually, that entails crimes, but not any crime committed was recognized a sin); b) unintentional sins, which required atonement for the people to be purified from them.

In addition, in view of the degree of social danger, there were: a) great sins, which included murder of a Brahmin, stealing gold, guru's bed desecration and communication with the above-mentioned people (Dharmashastra Manu, XI. 55; Dharmashastra Yajnavalkya, III. 232); b) sins equal to the great ones (for example, murder of a Brahmin equated to the impudent censure of the teachers, admonition of the Veda, homicide, forgetfulness of the Veda; eating the forbidden food, deception and lies when defining superiority in gentility, a kiss of the menstruating woman were equated to drunkenness; stealing a horse, jewels, men, women, land, cows, donations was equated to theft of gold, sexual relations with a friend's wife, young girls, with half-sisters, low-caste women, with women from the same family, with son's wives was equal to guru's bed desecration (Dharmashastra Manu XI. 56-59; Dharmashastra Yajnavalkya, III. 228-231); c) smaller sins were: leaving families to the mercy of fate, non-payment of debts, teaching Veda for a fee, non-lighting fire, sale of prohibited goods, doing disapproved work, cheating, stealing grain, non-precious metals, cattle, etc. (Dharmashastra Manu, XI. 60-67; Dharmashastr Yajnavalkya, III. 234-242).

Except the said three types Dharmashastra Manu specifies another four types of sins that entail deprivation of caste, rebirth in a mixed caste, etc. (Dharmashastra Manu, XI. 68-71).

By imposing and execution of the sin redemption all sins can be classified into: a) obvious sins to be atoned through the established by the Parishad's decision procedures. Dharmashastra precept Parishad to take into consideration thoroughly the place and time of sin committing, the age and physical abilities of the sinner for imposing redemption. Special ("lightweight") redemption was impos Dionisiana ed on children, the elderly and the sick (Dharmashastr Manu, II. 220).

b) unacknowledged sins could be purged without addressing Parishad through by the covert redemption. In the medieval commentarial literature it was stated that "twice-born, not inclined to sin condoning, knowledgeable of the essence of the Vedas, Shasters and truth" could be purged through covert redemption (Romanovskaya, 2014). Covert redemption included bread-holding, mantras uttering, fasting, offering sacrifices in the fire and whispered recitation of prayers.

Previously mentioned willful sins, characterized as acts, which were to be not only retributed, but punished as well by the secular court, they are, in particular, the sins of the category of "great" ones. For example, guru's bed desecration on the one hand, was punished with putting to death (Dharmashastra Yajnavalkya, III. 233), and, on the other hand, it was regarded as a great sin, which could be redeemed in a certain way (Dharmashastr Yajnavalkya, III. 259). On the other hand, some acts were recognized sinful but not criminal (so-called "unintentional sins"), as well as some criminal offenses were not seen as sinful (for example, error in scales measurement, adulteration of coinage, destruction of irrigation facilities, etc.).

The fact that a sin and a crime were delineated is proved by Article 210 of Chapter II of Dharmashastra Yajnavalkya where a secular punishment for false accusation of committing a sin is established: "When accusing someone of sin committing which entails caste deprivation, the guilty must be pressed to pay a an average Sahas fine, but the charge for committing a lesser sin is the first Sahas fine".

This all proves the fact that dharmashastra despite the ambiguous terminology used in it, had a clear distinction between a sin and a crime.

\section{Conclusions}

Summarizing the study of the Oriental and Western approaches to the concepts of sin and crime, redemption and punishment, it should be emphasized that "there are similar concepts, general trends in the legal thought development in such distant regions with quite different religious beliefs". This fact once more emphasizes that the law is based on moral values to be universal for all people, regardless of their religious and ethnic background. Both the Oriental and the Western traditions of religious and philosophical apprehension of life gave rise to the corresponding to the concept rules governing person's private life, his/her relationship with himself/herself, with the family, with other people and, of course, with God.

Some of these rules were moral and ethical, and some were absolutely legal and other rules were a mixture of moral and legal ones. 
In the course of the millennium the legal religious norms were replaced by the secular ones, the modern "western world" is the world of the secularized law. The law as a factor of strength protects than educates someone. It proclaims the personal rights, including self-expression rights and provides these rights. Religious rules educate rather than protect, they press to observe the duties, not to claim the rights. The problem of legal and religious regulations influence onto the personality appears to have been and to be important. For thousands of years, religion provided the impact on the human behavior motivation, influenced by religious attitudes the people's legal awareness was evolving. Nowadays, the ethical norms (religious and moral) still have not lost their significance and continue to affect the person's privacy, which is better seen in the Middle East where they more reverently treat their traditions.

\section{Acknowledgment}

The authors are very grateful to and admire our outstanding world-famous fellow man Harold J.Berman for his notable papers in the sphere of law history to have greatly affected the authors' scientific views.

\section{References}

Berman, Harold J. Law and Revolution: The Formation of the Western Legal Tradition. - Cambridge: Harvard University Press, 1983.

Beznosova, Ya. V., Kondratyeva, A. N., Romanovskaya, V. B., Fedyushkina, A. I. Religious Law and Men's Private Life in Western and Oriental Traditions B (by the example of Canon Law of the Catholic Church and Hindu Dharmashastra) // Legal Science and Practice: Bulletin of the Nizhny Novgorod Academy of Russia's. - 2015. - No. 1.

Brandt, J. Das Reformpapsttum und die Bekämpfung der Simonie und des Nikolaitismus. - München, GRIN Verlag GmbH., 2007.

Collectio Dionysiana // Patrologiae cursus completus latinus /Ed. J. I. Migne. Vol 67.

Collectio Vêtus Gallica /Ed. IL Mordek // Mordek. Kirchenrechtund Reform im Frankenreich. - Berlin; New York, 1975.

Divus Ivo Carnotensis. Décretum // Patrologiae cursus comptetus... Series latina /Ed. J. P. Migne. Vol. 161. Cot. 47-60.

Gausrat, A. Medieval Reformers: Pierre Abailard, Arnaldo da Brescia / Transl. from German. 2nd edit. - M.: Librokom, 2012.

Gratianus. Concordia discordantium canonum // Patrologiae cursus completus... Series latina / Ed. J. P. Migne. Vol. 187.

Jayaswal, K. P. Manu and Yiajnavalkya. - Calcutta, 1930.

Kempf, F. Die mittelalterliche Kirche. Erster Halbband: Vom kirchlichen Frühmittelalter zur gregorianischen Reform, in: Handbuch der Kirchengeschichte III,1. - Freiburg, 1966.

Landau, P. Europäische Rechtsgeschichte und kanonisches Recht im Mittelalter. Wissenschaftlicher Verlag Bachmann. - Badenweiler, 2013.

Lubin, T. Punishment and expiation: overlapping domains in brahmanical law // Indologica Taurinensia. - 2007. - № 33.

Menski, W. Postmodern Hindu law. - SOAS Law Department Occasional Papers . 2001.

Olivelle, P. The law code of Many. A new translation by Patrick Olivelle. - Oxford: Oxford University Press, 2009.

Romanovskaya, V. B. The Revival of the Vedic Knowledge of Society in the Modern World. Bulletin of Lobachevsky Nizhny Novgorod University. Series: Social Sciences. - 2014. - No.1.

Samozvatsev, A. M. The Book of Yajnavalkya Sage. - M.: Publishing Firm "Vostochnaya Literatura" RAN, 1994.

Samozvatsev, A. M. The problem of Ancient Indian Law // Bulletin of Ancient History. - 2001. - No.4.

Sprandel, R. Ivo von Chartres und seine Stellung in der Kirchengeschichte. -Hiersemann, Stuttgart, 1962.

Stiegler, M. A. Dispensation und Dispensationswesen in ihrer geschichtlichen Entwickelung bis zum IX. Jahrhundert. 1897.

Winroth, A. The Making of Gratian`s Decretum. - Cambridge University Press, 2004.

Yajnavalkya's Gesetzbuch Sanskrit und Deutsch herausgegeben von A. - F. Stenzler. - B. - L., 1849.

Yesipov, V. V. Sin and Crime, Sacrilege and Larceny / Yesipov V.V., Prof. of Warsaw University. - St. Petersburg: Publ. House of A.F. Marks, 1894. 